\title{
Fulani cattle productivity and management in the Kachia Grazing Reserve, Nigeria
}

Marie Julie Ducrotoy ${ }^{1 *}$, Ayodele O. Majekodunmi ${ }^{1,2}$, Alexandra P. M. Shaw ${ }^{1,3}$, Husein Bagulo², Usman Baba Musa ${ }^{4}$, Wilson J. Bertu ${ }^{5}$, Amahyel Madu Gusi ${ }^{5}$, Reuben A. Ocholi ${ }^{5}$, Ward Bryssinckx ${ }^{2}$ and Susan C. Welburn ${ }^{1}$

\begin{abstract}
Kachia Grazing Reserve (KGR) in northern Nigeria was home to some 10,000 Fulani pastoralists and their 40,000 cattle in June 2011. This study examines productivity and management of cattle belonging to livestock keepers within the reserve before and after a mass immigration event when 3,000 refugees moved into the reserve with their cattle to escape inter-community violence during May 2011. Data, on livestock management strategies (transhumance) and production parameters (herd size, composition, fertility, dynamics), were collected in March, June and October 2011.

Cattle productivity in KGR is geared to supporting Fulani households while maintaining herd wealth. High offtake of young animals, especially the selling of heifers, was an unusual finding and may indicate that KGR pastoralists have been restricting their herd size voluntarily as well as limiting milk production to household requirements. This is probably due to the absence of a commercial milk market and a higher reliance on the sale of young stock to meet cash needs.

Despite the widespread perception that grazing reserves are promoting sedentarisation of Fulani pastoralists and curbing transhumance, the inhabitants of the KGR were observed to practise wide-ranging transhumance both during wet and dry seasons driven by the limited availability of grazing. Some households selected a sub-sample of animals for transhumance rather than sending their whole herd, and some maintained cattle on alternative land-holdings outside the reserve. KGR households described modifying their usual transhumance practices in response to the mass immigration event and insecurity.

Nevertheless, the herd demography results from this study are broadly similar to data obtained from other studies over the past 40 years, indicating that productivity and management practices have remained relatively unchanged.
\end{abstract}

Keywords: Fulani, Cattle, Pastoralist, Productivity, Transhumance, Conflict, Nigeria, Grazing reserve

\section{Introduction}

Fulani is the Hausa word for the pastoral peoples of Nigeria belonging to the 'Fulbe' migratory ethnic group. The Fulani rear the majority of Nigeria's cattle, traditionally estimated at $83 \%$ pastoral, $17 \%$ village cattle and $0.3 \%$ peri-urban (Resource Inventory and Management 1992).

Cattle fulfil multiple roles in agro-pastoralist communities, providing meat, milk and draught power while sales of stock generate income and provide insurance

\footnotetext{
* Correspondence: marie.ducrotoy@gmail.com

${ }^{1}$ Division of Infection and Pathway Medicine, School of Biomedical Sciences, College of Medicine and Veterinary Medicine, The University of Edinburgh, Chancellor's Building, 49 Little France Crescent, Edinburgh EH16 4SB, UK Full list of author information is available at the end of the article
}

against disasters. They also play a key role in status and prestige and for cementing social relationships such as kinship and marriage (Bonfiglioli 1993). For pastoralists, cattle represent the major household asset.

Pastoralism, as a livelihood, is coming under increased pressure across Africa, due to changing social, economic, political and environmental conditions. Prior to the 1950s, a symbiotic relationship existed between pastoralists, crop farmers and their environment with pastoralists practising transhumance. During the dry season, pastoralists migrated to the southern parts of the Guinea savannah zone, where there was ample pasture and a lower density of crop farmers. In the wet season, these areas faced high challenge from African animal trypanosomiasis transmitted by tsetse flies, so pastoralists would 
migrate to visit farmlands within the northern Sudan savannah zone, supplying dairy products to the local farming community. Reciprocally, the farming community supplied pastoralists with grain, and after the harvest, cattle were permitted to graze on crop residues in fields leaving behind valuable manure.

Population pressure on land has resulted in deforestation and settlement in the Guinea savannah and rainforest regions. Autonomous control of tsetse and trypanosomiasis (Bourn et al. 2001) has enabled cattle and crop farmers to inhabit these zones all year round, increasing competition for resources and land (Azuwike and Enwerem 2010). Grazing zones and transhumance routes have come under mounting pressure, increasingly encroached by farmland. Fulani have few or no rights to land, leading to increasing local conflict, when transhumant herds damage crops. Changing climatic conditions are also driving desertification, reducing access to water and pasture while increasing food insecurity in the Sahel region (Blench 1996).

Grazing reserves were established during the 1960s in an attempt to provide the Fulani with secure land tenure and to modernise the livestock sector, away from traditional practices of cattle transhumance. Emphasis was placed on settlement or 'sedentarisation' of nomadic pastoralists, with a view to reducing opportunities for farmer-pastoralist conflict (Suleiman 1986).

The Grazing Reserve Act was passed in 1964 (WatersBayer and Taylor-Powell 1984a; Awogbade 1987; Ingawa et al. 1989). Between 1970 and 1980, the federal and state governments invested 120 million Naira (70 million USD) in livestock development, 70\% of which was allocated for grazing reserves. While the selection and acquisition of grazing lands was the responsibility of individual states, the reserves were implemented through the National Livestock Project Unit (NLPU) of the Federal Livestock Department, now the National Livestock Project Department, who were responsible for infrastructure development, e.g. provision of boreholes, dams, schools and roads (Ingawa et al. 1989). However, pastoralists were dissuaded from settling within reserves by the absence of formal gazetting, the lack of legalised grazing and land ownership and slow government investment in infrastructure (Waters-Bayer and Taylor-Powell 1984a).

Many states were dissuaded from establishing reserves due to the high levels of land compensation that were recommended by the Federal Land Use Act, 1978 (Waters-Bayer and Taylor-Powell 1984a). The Ministry of Agriculture declared in 1981 that 22 million ha should be converted to grazing reserves, but by 1980 , only 2.3 million ha had been acquired (Oxby 1982). Nigeria has 415 grazing reserves, but only one third is in use, as the remainder is established on farmland (Integrated Regional Information Network 2009a). Only 24 reserves have been gazetted by government and have the rights to services as set out in the grazing reserve laws (von Kaufmann et al. 1986).

Kachia Grazing Reserve (KGR) was established by the Kaduna State Ministry of Animal and Forest Resources in 1967 to settle nomads in one location to improve their standard of living, to improve the quality of livestock produced, to reduce conflict between nomads and farmers and to provide an area for research (Waters-Bayer and Taylor-Powell 1984a). At inception in 1967, KGR was sprayed with insecticide and declared tsetse free to encourage pastoralist settlement. Only a decade later was the Ministry of Agriculture assigned to map out strategies for water and pasture development. KGR was eventually re-officialised in 1988 and formally gazetted in 1996. During the 1980s, heavy investments in the KGR were made by the government, NLPU and the International Livestock Centre for Africa (ILCA). ILCA commissioned a large livestock production programme in 1978, and KGR has been unusually protected by an international presence.

The settlers were initially concentrated in a small area of the southeast of KGR close to the administrative camp. By 1984, 34 Fulani households had settled in the KGR but none were nomadic; all were indigenous to the area and farmed food crops around their settlement (Oxby 1984). Transhumant migratory Fulani did, however, visit KGR for dry season grazing, diverting from their transhumance route (Waters-Bayer and TaylorPowell 1984a).

Since the end of military rule in 1999 in Nigeria, there have been numerous intermittent outbreaks of armed conflict. The violent ethno-religious conflicts in northcentral Nigeria followed the shift from centralised military government to decentralised democratic government and competition and conflict over political posts and public resources. The 'middle belt' lies between the Muslim north and Christian south with most states hosting large populations that are divided along ethnic and religious lines.

Religious and political leaders have exploited inherent tensions within communities that are increasingly under pressure, driving people to vent their frustration through acts of violence, religious extremism and increasing acts of terrorism (Integrated Regional Information Network 2009a; 2009b; 2009c; 2010a; 2010b; 2010c).

This study examines the productivity and management of cattle belonging to livestock keepers within the KGR during a period of intense pressure. During May 2011, 3,000 refugees moved into the reserve, with their cattle, to escape post-election inter-community violence. The study is synchronic, with data being collected during three longitudinal visits to KGR between March and October 2011 during this period of political upheaval. 
Two main themes are explored: livestock management strategies (transhumance and herd splitting) and production parameters (herd size, composition, fertility, dynamics).

\section{Study area}

The KGR is situated in northern Nigeria in the middle belt or sub-humid zone between $10^{\circ} 03^{\prime}$ to $10^{\circ} 13^{\prime} \mathrm{N}$ and $7^{\circ} 55^{\prime}$ to $8^{\circ} 06^{\prime} \mathrm{E}$ (Figure 1). It has an area of 33,411 ha and lies north and west of the major migration routes followed by transhumant Fulani based in the Kano and Bauchi areas. KGR is subdivided into six administrative blocks each of which shows variations in demographics and ecological characteristics (Figure 1).

The reserve has a tropical sub-humid climate with annual rainfall of between 1,000 and 1,200 $\mathrm{mm}$ and an average temperature of $28{ }^{\circ} \mathrm{C}$. The wet season lasts from May/June through to October while the dry season lasts from November through to May/June. KGR inhabitants have been reporting a worsening delay in onset of the wet season year-on-year, in line with climatic trends of desertification in the Sahel.

The KGR is an 'agro-pastoral' or mixed herding and cultivation system. Sources of income of KGR households include a combination of sales of livestock, livestock products (milk) and, to a much lesser extent, crop sales and off-farm activities including trade (business), salary (formal employment) and daily wage (casual labour). Livestock is considered as the main source of income and subsistence. However, around 90\% of households in the KGR grow crops, mostly for subsistence.

In June 2011, KGR was home to 777 households with human, cattle, sheep and goat populations of approximately $10,000,40,000,10,000$ and 5,000, respectively (Ducrotoy 2015). Of the 752 households for which census data on year of settlement in KGR was available, $28.2 \%$ were established in the KGR before the period of inter-communal violence which began in the early 2000s. A further $38.7 \%$ settled in KGR between 2001 and 2010. In May 2011, 3,000 Fulani (33.1\% of all households) moved into KGR to escape the inter-communal violence that erupted in April 2011 after the elections. Of the 249 households that immigrated into KGR in May 2011, all still inhabited the reserve in October 2011, and focus group discussions suggested they would not return to where they had lived previously. Households that moved into KGR during the mass immigration event of May 2011 are referred to as 'new immigrants' and the remainder as 'old settlers'.

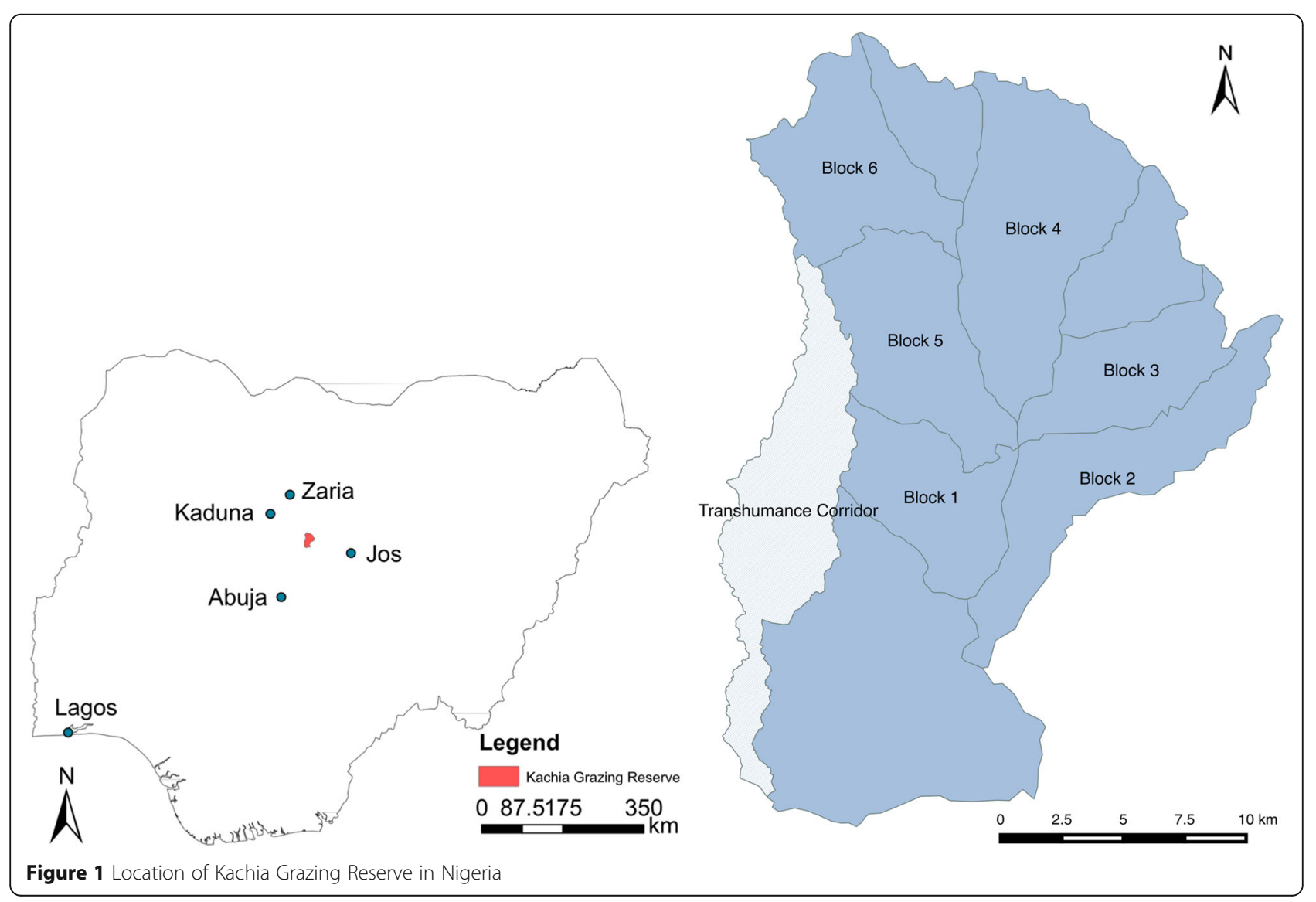




\section{Methods}

\section{Data collection}

Data were collected longitudinally, in March, June and October 2011. The data were derived from censuses, individual cattle histories, household questionnaires, focus group discussions and from key informant interviews (Table 1 ).

\section{Censuses, surveys and sampling}

A census undertaken by the KGR Project Office (state government) in July 2010 was used as the sample frame for the March 2011 survey. Following the mass immigration event of May 2011, a second census was conducted in collaboration with the Project Office in June 2011 to update the sampling frame for the June and October surveys.

The three cross-sectional surveys undertaken in March, June and October 2011 were designed to determine the prevalence of trypanosomiasis, brucellosis, tuberculosis and helminths in livestock and for brucellosis in humans. Cluster sampling methodology (Bennett et al. 1991; Thrusfield 2007) was used to determine sample size, fixed to fulfil the trypanosomiasis survey assumptions in March and human brucellosis survey assumptions in June to October.

Survey parameters in March consisted of anticipated trypanosomiasis prevalence $45 \%$ (Majekodunmi et al. 2013), desired precision of sample estimate 5\%, degree of confidence $95 \%$ and intra-cluster correlation coefficient 0.18 (Majekodunmi et al. 2013). Survey parameters for June to October consisted of anticipated brucellosis prevalence 21\% (Alausa and Awoseyi 1976), desired precision of sample estimate $5 \%$, degree of confidence 95\% and intra-cluster coefficient 0.20.

Sample sizes were then tested for adequacy in terms of precision at specified levels of confidence for each specific disease combination. The number of clusters (households) required was 88 and 79 for the March and June to October surveys, respectively. Households were randomly selected by assigning numbers and the subsequent generation of 88 and 79 random numbers from the June and March sampling frames, respectively. For each cluster (household), all cattle were sampled, cattle histories were collected and a questionnaire was administered.

For the survey undertaken in March 2011, 88 households were not available due to the number of herds having left the KGR on transhumance (Table 1). The March survey was undertaken before the mass immigration of May 2011.

For the survey undertaken in June 2011, only 40 households were surveyed due to the logistical constraints of tuberculin testing in cattle necessitating two household visits. Of those 40 households, 16 were new immigrants and 24 old settlers.

Human sampling was undertaken in October in the original 40 households sampled during the June animal survey and in an additional 41 households. As 40 of the 81 households sampled in October had already had questionnaires administered in June, an additional 41 households were administered questionnaires in October (Table 1). Of those 41 households, 11 were new immigrants and 30 old settlers.

The coincidence of the refugee influx with the study was an unexpected and unpredictable event. As data was

Table 1 Summary of data collection activities

\begin{tabular}{|c|c|c|c|}
\hline \multirow[t]{2}{*}{ Data source } & \multicolumn{3}{|c|}{ Data collected and sample size (no. HH/focus group discussions/key informant interviews) } \\
\hline & March & June & October \\
\hline Census & $(0)$ & Herd size, transhumance $(724)^{a}$ & (0) \\
\hline Cattle histories & Herd composition and fertility $(49)^{b}$ & Herd composition and fertility (40) & $(0)$ \\
\hline Questionnaires & Herd size, transhumance $(57)^{c}$ & $\begin{array}{l}\text { Herd size, transhumance, composition, } \\
\text { dynamics and productivity }(40)^{\mathrm{d}}\end{array}$ & Herd size, transhumance $(41)^{d}$ \\
\hline Focus group discussion & \multicolumn{3}{|l|}{$\begin{array}{l}\text { Herd management calendar and } \\
\text { transhumance (4) } \\
\text { Human immigration patterns into } \\
\text { the KGR over time (4) } \\
\text { Herd dynamics: calving, deaths, sales, } \\
\text { slaughter, purchases and gifts ( } 2 \text { ) } \\
\text { Future of pastoralism (2) }\end{array}$} \\
\hline Key informant interview & \multicolumn{3}{|l|}{$\begin{array}{l}\text { Transhumance and livestock ownership (2) } \\
\text { KGR past and future (2) } \\
\text { Prospects for pastoralism, transhumance } \\
\text { and grazing reserves (2) }\end{array}$} \\
\hline
\end{tabular}


collected in different seasons, the before influx data from March could not be strictly compared to the post influx data collected in June and October. Nevertheless, some same season/survey comparisons could be made to gauge differences between non-grazing reserve (represented by new immigrants) and grazing reserve (represented by old settlers) settings.

Households were defined as individual ruga (homesteads) as the unit of interest for the local project office (state government). A ruga consists of a man, his wife or wives, unmarried children and dependent parents. Multiple ruga make up a wuro or extended household representing a cattle-owning entity headed by the household head, even though individual cattle belong to different family members and ruga. The wuro consists of a collection of huts belonging to members of the same family.

Questionnaire estimates represent cattle ownership at the level of the wuro whereas cattle histories and census estimates are for individual ruga. Since Fulani needed to take their herds for grazing, households were only willing to make one sub-group owned by a single ruga available for sampling. Cross-checking on cattle numbers was undertaken by comparing overall cattle numbers to the total obtained by adding up animals by age/sex category.

\section{Cattle histories}

For each animal sampled, data were collected on age, sex and life stage (calf, cow, heifer, bull, steer, draught oxen) and total parity to date for all cows. Cattle have individual names, and the head of the household and his sons were able to recount the age and reproductive history of each animal with high accuracy as previously observed (Swift 1981). Information provided was confirmed by comparison with the age according to dentition (accurate to 5 years). No cattle were sampled in October 2011.

The survey undertaken in March 2011 fell during the middle of the dry season when $40 \%$ of households had taken their herd on dry season transhumance. Data from this period reflect a biased sub-sample of herds and sub-herds left behind. Herd composition analysis has been undertaken for households sampled for whom a percentage of the herd was away on transhumance $(n=26)$ and those for whom all cattle were in $\operatorname{KGR}(n=23)$.

Certain households sampled in March 2011 were excluded from analysis. These included herds for which data was collected for $<80 \%$ of the herd $(n=7)$, herds with undefined transhumance status $(\mathrm{n}=7)$ and a single herd that was 'passing through' KGR.

The survey undertaken in June 2011 coincided with the beginning of the wet season during which the majority of animals return to the KGR, and of all herds selected, none had animals away on transhumance.

Herd composition reflects the sub-herds managed by the household in the KGR and not the aggregate of all herds managed by the household including cattle kept on other holdings. Herd composition data reflects the sex and age of animals managed by a ruga.

\section{Questionnaires}

A questionnaire was administered to each selected household during March, June and October 2011. Data captured varied with each sampling period (Table 1).

Herd dynamics data (entries and exits into the herd) were obtained during the survey undertaken in June 2011. Events of social importance such as Ramadan, the Eid el Fitr religious festival and seasons were used to define the beginning of each 12-month period of interest. Data were collected on price of cattle sold or purchased and the reasons for sale, slaughter, gifting, purchase or death. Animals slaughtered due to ill health were counted as deaths on the assumption that they would have died.

Questionnaires were administered with the assistance of a translator. Respondents were household heads or, in a minority of cases, their sons or brothers, all of whom have intimate knowledge of livestock management issues.

\section{Focus group discussions and key informant interviews}

Participatory epidemiology and participatory rural appraisal techniques (Catley et al. 2012; Catley 2006; Chambers 1994; Swift 1981) were employed in this study (Table 1). Focus group discussions were undertaken with 6 to 12 individuals of the same sex. The questions were translated into Hausa or Fulfulde (Fulani understand and speak both) by an interpreter, who translated answers back into English. Discussions on specific topics were repeated until saturation was reached. Key informant interviews were undertaken in English if the respondent(s) understood English or with the assistance of a translator if not.

\section{Data analysis}

Descriptive statistics are presented in tables and bar charts.

Association between predictor variables and response variables were examined using the nonparametric test Kruskal-Wallis in Minitab $^{\circ}$ as data subject to this test were not normally distributed. Kruskal-Wallis tests the equality of medians of two or more populations (null hypothesis or H0: the population medians are all equal versus alternative hypothesis or $\mathrm{H} 1$ : the medians are not all equal). 
Pearson's chi-squared test was applied to sets of categorical data to evaluate statistical significance of differences between old settler and new immigrant households.

Focus group discussant and key informant verbal data were translated from Hausa or Fulfulde to English and transcribed verbatim in situ as unstructured text. Qualitative text data were typed into Microsoft Word $^{\circ}$. The first author reviewed all transcripts as the first step of undertaking a framework analysis. After familiarisation with the data, the following recurrent themes were identified: herd management calendar and transhumance; human immigration into KGR; sale, purchase and productivity of cattle; and the future of pastoralism.

Textual codes were used to identify data corresponding to different themes using traditional methods (reading through the transcript and assigning codes, cutting pages up into coded passages and manually sorting the coded text to analyse patterns). Charts were created to group data belonging to the same theme. Mapping and interpretation was used to identify patterns, contradictions and respondent clusters in thematically grouped data.

For all themes except the future of pastoralism, focus group results and key informant interviews are used to back up the results of the questionnaires, cattle histories and census.

\section{Results}

\section{Herd size and herd splitting}

The mean herd size varied across survey, data source, assessment unit and method (Table 2). Nearly $40 \%$ of households split their herds into a sub-herd maintained in KGR and a separate reserve herd kept outside of KGR. The average size of herds maintained in KGR increased from 83 cattle in March 2011 to 129 in June 2011 and subsequently decreased to 81 in October 2011 (Table 2).

Focus group discussions revealed that the inflation in the June estimate was due to the new immigrant households and their larger herds:

When the new settlers fled from the violence they had to bring all of their animals with them to the KGR and their herds are larger than the ones we are used to here. (focus group discussion, old settler)

By October, new immigrants had reduced their herd size bringing the average in line with the March 2011 figure:

There is not enough grazing for all my animals here [in KGR] so I needed to send some away to be looked after by relatives. (focus group discussion, new immigrant)

These statements corroborate the statistically significant difference in median cattle herd size kept in KGR between new immigrants and old settlers for the June data and the absence of a statistically significant difference in October. In June, the 16 new immigrant households sampled had a median cattle herd size of 99 compared to the 24 old settler households, found to have a median cattle herd size of $50 . p$ values $(0.0027)$ for the Kruskal-Wallis test $(H=8.97, \mathrm{DF}=1)$ indicate there

Table 2 Comparison of herd size estimates across different surveys and data sources

\begin{tabular}{|c|c|c|c|c|c|}
\hline Data source & Assessment method & Unit of interest & No. of $\mathrm{HH}$ & Total cattle & Average/HH \\
\hline \multicolumn{6}{|c|}{ March 2011 survey $(64 \mathrm{HH})$} \\
\hline Questionnaire & How many cattle does your HH keep in the KGR? & Wuro & 57 & 4,730 & 83.0 \\
\hline Cattle histories & Cattle sampled from selected $\mathrm{HH}$ & Ruga & 49 & 1,653 & 33.7 \\
\hline \multicolumn{6}{|c|}{ June 2011 census (724 HH) } \\
\hline Government census & Number of cattle managed by $\mathrm{HH}$ in the KGR & Ruga & 724 & 41,234 & 57.0 \\
\hline \multicolumn{6}{|l|}{ June 2011 survey $(40 \mathrm{HH})$} \\
\hline \multirow[t]{3}{*}{ Questionnaire } & $\begin{array}{l}\text { How many cattle does your HH own, including } \\
\text { cattle kept on holdings outside KGR? }\end{array}$ & Wuro & 40 & 6,264 & 156.6 \\
\hline & Cattle kept in KGR & & 40 & 5,140 & 128.5 \\
\hline & Cattle kept on other holdings & & 15 & 1,124 & 74.9 \\
\hline Cattle histories & Cattle sampled from selected $\mathrm{HH}$ & Ruga & 40 & 1,981 & 49.5 \\
\hline Government census & Number of cattle managed by $\mathrm{HH}$ (cattle kept in KGR) & Ruga & 40 & 2,136 & 53.4 \\
\hline \multicolumn{6}{|c|}{ October 2011 survey (41 HH) } \\
\hline \multirow[t]{3}{*}{ Questionnaire } & $\begin{array}{l}\text { How many cattle does your HH own, including cattle } \\
\text { kept on holdings outside KGR? }\end{array}$ & Wuro & 41 & 4,405 & 107.4 \\
\hline & Cattle kept in KGR & & 41 & 3,330 & 81.2 \\
\hline & Cattle kept on other holdings & & 15 & 1,075 & 71.7 \\
\hline
\end{tabular}


is sufficient evidence that medians are not equal when alpha is set at 0.05 . By October, however, the 11 new households sampled were found to have a median cattle herd size of 77 and the 30 old settler households a herd size of 40 cattle. $p$ values $(0.3464)$ for Kruskal-Wallis $(H=0.89, \mathrm{DF}=1)$ reveal insufficient evidence to support that medians are different when alpha is set at 0.05 .

The average size of households' sub-herds kept on another holding was 75 in June 2011 and 72 in October 2011, slightly smaller than the KGR herd sizes.

At the ruga level, herd size estimates obtained during the June 2011 census (57.0) are similar to those estimated from the cattle histories for the same time period (49.5). This figure was higher than for March (33.7) reflecting the inclusion of 14 new immigrant households.

\section{Transhumance}

In March 2011, almost half of the KGR inhabitants had taken their entire herd on dry season migration. Households sampled included those that had kept at least some cattle in the reserve, although nearly $60 \%$ of those had sent a proportion of their herd away (Table 3).

Focus group discussions undertaken in March with young and old men both confirmed that dry season migration is an important herd management strategy, as illustrated by this quote from a young pastoralist:

Most people in KGR go on migration for 3 months of the dry season, searching for the crop residues of indigene farmers and fadama [Hausa word describing low lying well-watered land] areas for grazing.

In June 2011, after the onset of the rains, 25\% of households still had cattle away on migration, despite this being the time when all cattle usually return to the KGR:

Usually everyone who went on dry season migration brings their cattle back to the KGR as soon as they have word that the rains have come to KGR.
By October 2011, the proportion of households reporting sending animals away during both the wet and dry seasons was over $50 \%$. Overall, $90 \%$ of households reported practising some form of transhumance, which fits with a comment made by a village head during a focus group discussion:

Even when there is no crisis and there is general peace all over the north of the country, 95\% of the households in the KGR take animals out for migration. This is because cattle generally don't eat tree leaves and the tree constitutes the majority of the vegetation of the reserve. The flood plains further south have tree plants and shrubs that our animals can eat, but not here in KGR.

Some households leave animals behind at the KGR homestead rather than take the whole herd on transhumance (Figure 2). Keeping lactating females with young calves at foot within the KGR provides milk for the family (only a few family members accompany the cattle on transhumance). The stress induced by transhumance on very young calves, pregnant females in their last trimester and sick or old animals is to be avoided. Some households $(n=38)$ reported selecting animals 'randomly' where no specific selection criteria were applied. Others $(n=20)$ preferentially send sexually mature females to promote optimal fertility through better nutrition, leaving males at home as they can tolerate the poor grazing of KGR (Figure 2).

The proportion of the herd taken on dry and wet transhumance varied across the three surveys. While the number of herds staying in KGR for the entire dry and wet season reduced, the proportion of animals within herds taken on dry and wet transhumance increased between March and October 2011 (Figure 2). By October 2011, approximately $40 \%$ of households were reporting taking their entire herd out of KGR during the dry and another $40 \%$ during the wet season.

Table 3 Number of herds undertaking transhumance by season

\begin{tabular}{|c|c|c|c|c|c|c|}
\hline Data source & Question asked & No. of herds & $\begin{array}{l}\text { Dry only (D) } \\
\text { no. } \mathrm{HH}(\%)\end{array}$ & $\begin{array}{l}\text { Wet only (W) } \\
\text { no. } \mathrm{HH}(\%)\end{array}$ & $\begin{array}{l}\text { Dry and wet (D\&W) } \\
\text { no. } \mathrm{HH}(\%)\end{array}$ & $\begin{array}{l}\text { D or W or D\&W } \\
\text { no. } \mathrm{HH}(\%)\end{array}$ \\
\hline March questionnaire & $\begin{array}{l}\text { Did you take any cattle out } \\
\text { of the KGR in the last year? }\end{array}$ & 56 & $26(56.5)$ & $0(0)$ & $0(0)$ & $26(56.5)$ \\
\hline June census & $\begin{array}{l}\text { Are any of your cattle currently } \\
\text { away on transhumance? }\end{array}$ & 700 & NA & NA & NA & $175(25.0)$ \\
\hline June questionnaire & $\begin{array}{l}\text { Did you take your cattle on } \\
\text { transhumance during the last } \\
\text { dry and/or wet seasons? }\end{array}$ & 39 & $12(30.8)$ & $5(12.8)$ & $10(25.6)$ & $27(69.2)$ \\
\hline October questionnaire & $\begin{array}{l}\text { Did you take your cattle on } \\
\text { transhumance during the } \\
\text { last dry and/or wet seasons? }\end{array}$ & 38 & $10(26.3)$ & $4(10.5)$ & $20(52.6)$ & $34(89.5)$ \\
\hline
\end{tabular}




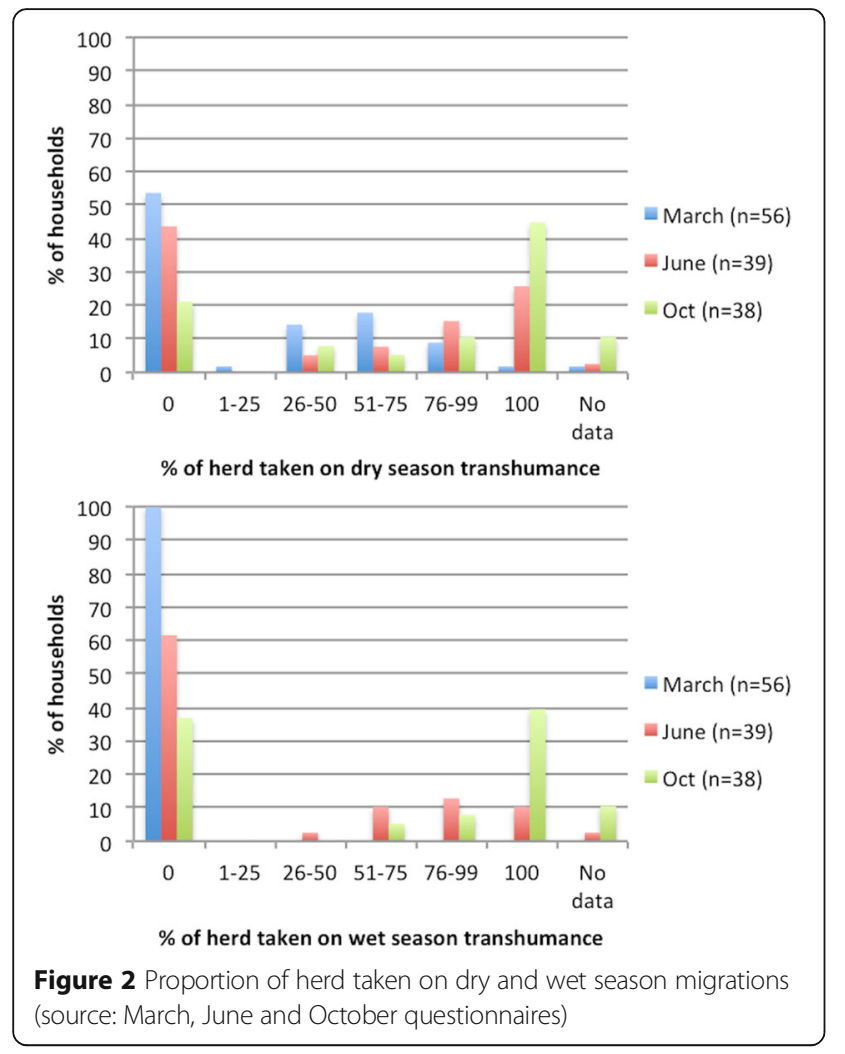

Most households reported leaving for dry season transhumance during November to December 2011 and returning at the onset of the wet season in May to June 2011. Wet season transhumance took place between June and November 2011. The duration of dry and wet season transhumance for old settlers and new immigrants was assessed in October (Table 4). Since new immigrants had, by then, only been in the KGR for only five months, this underestimated the time they spent on transhumance outside of KGR, especially during the dry season. Transhumance during both seasons was widely practised with most transhumant herds spending less than six months of the surveyed year in the KGR.

KGR inhabitants still adhere to the traditional practice of taking cattle north during the wet season and south during the dry season. Around $40 \%$ of households undertaking transhumance (dry and/or wet) travel between 40 and $80 \mathrm{~km}$, and $20 \%$ of households seek

Table 4 Average duration of dry and wet season transhumance out of the KGR over a one-year period

\begin{tabular}{|c|c|c|c|c|c|}
\hline \multirow{3}{*}{$\begin{array}{l}\text { Residence } \\
\text { status }\end{array}$} & \multirow{3}{*}{$\begin{array}{l}\text { Sample size } \\
\text { (no. herds) }\end{array}$} & \multicolumn{4}{|c|}{ Transhumance (months/year) } \\
\hline & & \multicolumn{2}{|l|}{ Dry } & \multicolumn{2}{|l|}{ Wet } \\
\hline & & Median & Mean & Median & Mean \\
\hline Old & 26 & 6.0 & 4.6 & 4.0 & 3.1 \\
\hline New & 8 & 1.0 & 1.8 & 2.0 & 2.5 \\
\hline All & 34 & 5.0 & 3.9 & 4.0 & 3.0 \\
\hline
\end{tabular}

pasture close to the KGR, within 20 to $30 \mathrm{~km}$. The remaining households travel 100 to $600 \mathrm{~km}$ to reach their destination of choice. Figure 3 shows that transhumance destinations are spatially dispersed but that most households stay close to home. Focus group discussions revealed that "most of those that go far away are new settlers or newcomers who have come in the last two years, those of us that have settled here for a long time do not go far' (Figure 3).

Eleven out of the $26(42 \%)$ new immigrant households for which data are available across the June to October surveys were found to partake in wet season migration, almost in line with the 28 out of $52(54 \%)$ old settler households, demonstrating that the arrival of the refugees had an impact both on the new immigrants themselves but also on the previous residents of KGR. Focus group discussions in March on the livestock management calendar emphasised that KGR households, prior to the mass influx of people and cattle in June, did not habitually practise wet season migration:

During the wet season most people will stay in KGR because they cannot cross the rivers and they like to have animals close to home so that both they and their cattle can rest, even if there are tsetse flies around in KGR. Early settlers hardly go away on migration during rainy season. (Old KGR resident)

When asked why the household head chooses a particular location for transhumance, over half of the responses $(65.5 \%)$ referred to better grazing. The June and October 2011 surveys coincided with a period of postelection violence, which explains why over $20 \%$ stated absence of violence as a primary criterion. Only two households (2.4\%) mentioned absence of tsetse as a motivational factor. A few households (8.3\%) mentioned they had family members there and that they were 'used to the place, $56.0 \%$ of whom stated that they returned to the same general area annually.

One or two young men usually accompany cattle on their transhumance. The household head decides which cattle go on transhumance and sends one or more of his son(s) or brother(s) with the cattle. Some households will employ young herd boys (not always Fulani). According to the March survey, the majority of respondents $(68 \%)$ stated that herding during transhumance was the role of the oldest son of the household head. Transhumance is a huge responsibility and physical challenge, so the most experienced and fittest household members are selected. Focus group discussions revealed that the men camp in the wilderness, sometimes for weeks, until they reach their final destination, after which time they usually stay at the homestead of family members living in that area. 


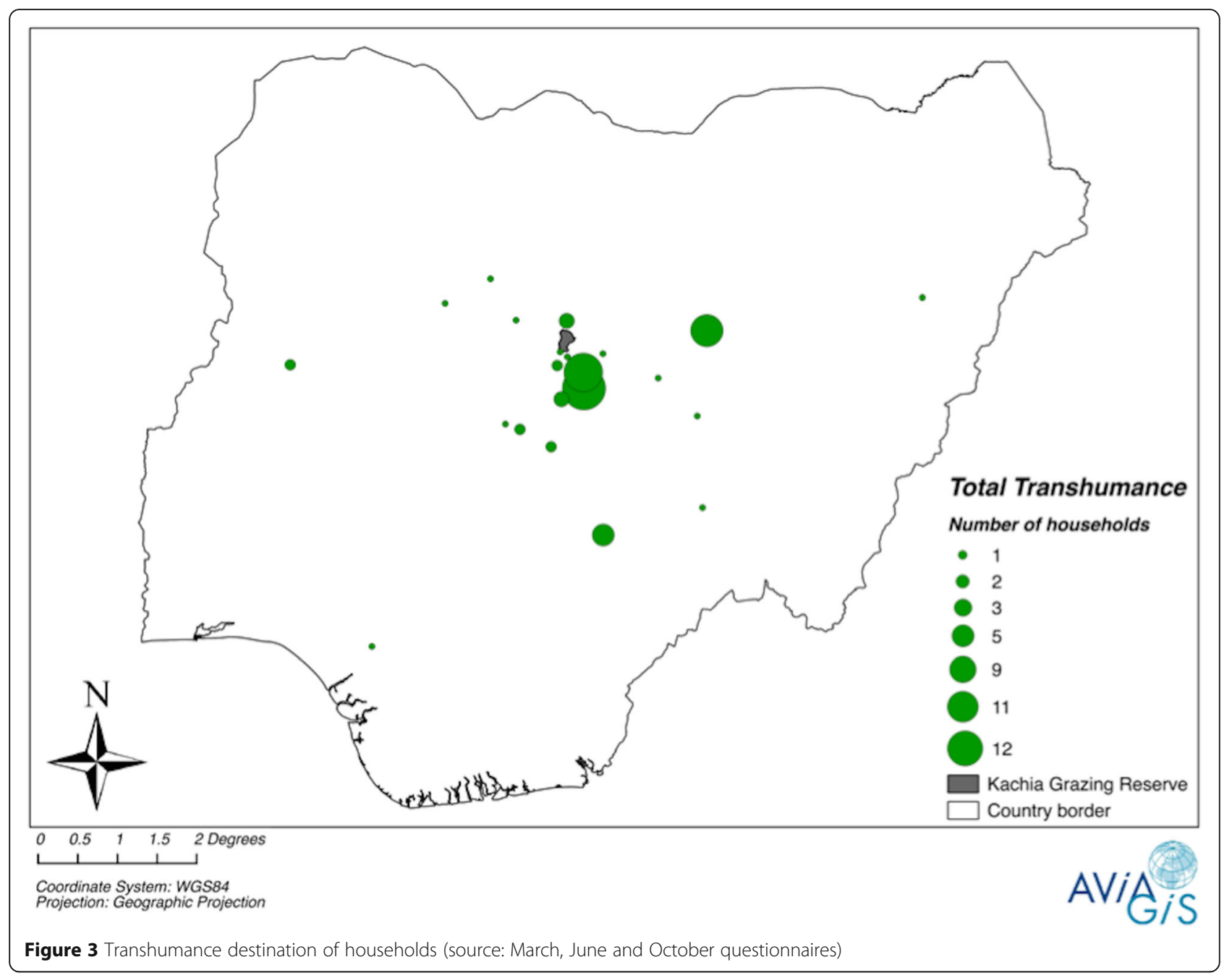

\section{Herd composition}

Herd composition was relatively consistent across surveys (Table 5). Sub-herds that stayed at the homestead in the March survey had a lower proportion of three- to four-year-old heifers and a higher proportion of old cows, suggestive of households preferentially sending young females on transhumance to help get them in calf and leaving old cows at home. Very few households (1 out of 49 in March and 6 out of 40 in June) kept ploughing oxen, and castration was practised on a proportion of males of three to four years old.

The frequency distribution of the different 'life stages' (aggregate of age, sex and reproductive status) is shown in Figure 4. Females outnumbered males in all categories, even calves and juveniles. Females aged five to seven years old were the largest category. Most un-calved sexually mature females were three to four years old, although some older females aged five to seven years were also reported as not having calved (Figure 4).

Herd composition, derived from aggregated cattle history data from March and June, is compared with data from other Nigerian studies in Table 6. Comparison of same season herd composition data derived from June cattle histories revealed old settler households had a higher overall percentage of male calves but a lower overall percentage of bulls; these were the only statistically significant differences at the $5 \%$ level (Table 7 ).

\section{Herd productivity and dynamics}

Herd dynamics reflect entries (births, purchases) and exits (deaths, sales, slaughter and giving away of animals as gifts). The March and June 2011 cattle history data were analysed to examine fertility. Questionnaire data from June 2011 was used to investigate all herd entries and exits. Focus group information on productivity, sales and purchases is examined.

\section{Fertility}

The age of first calving for females in KGR can be estimated by examining data on the age of individual heifers and cows which have given birth to zero and one calf, respectively (Table 8 ). Female cattle with no calves had a 
Table 5 Detailed herd composition

\begin{tabular}{|c|c|c|c|c|c|c|}
\hline \multirow{3}{*}{$\begin{array}{l}\text { Life stage } \\
\text { (age in years) }\end{array}$} & \multicolumn{4}{|c|}{ March } & \multirow{2}{*}{\multicolumn{2}{|c|}{$\begin{array}{l}\text { June } \\
\text { Complete } \\
\text { herd }^{f}\end{array}$}} \\
\hline & \multicolumn{2}{|c|}{$\begin{array}{l}\text { Complete } \\
\text { herd }^{\dagger}\end{array}$} & \multicolumn{2}{|c|}{$\begin{array}{l}\text { Non transhumant } \\
\text { sub-herd }^{g}\end{array}$} & & \\
\hline & No. & $\%$ & No. & $\%$ & No. & $\%$ \\
\hline Calf female $(<1)$ & 63 & 9.2 & 55 & 7.9 & 130 & 6.6 \\
\hline Calf male $(<1)$ & 41 & 6.0 & 38 & 5.5 & 125 & 6.3 \\
\hline Juvenile female ( 1 to 2 ) & 93 & 13.5 & 76 & 11.0 & 271 & 13.7 \\
\hline Juvenile male (1 to 2 ) & 88 & 12.8 & 99 & 14.3 & 191 & 9.6 \\
\hline Steer $^{\mathrm{a}}$ (3 to 4 ) & 32 & 4.7 & 23 & 3.3 & 6 & 0.3 \\
\hline Steer ( 5 to 7 ) & 3 & 0.4 & 7 & 1.0 & 23 & 1.2 \\
\hline Steer (8 to 10 ) & 0 & 0.0 & 5 & 0.7 & 6 & 0.3 \\
\hline Steer $(>10)$ & 0 & 0.0 & 0 & 0.0 & 2 & 0.1 \\
\hline Bull $^{b}$ (3 to 4 ) & 32 & 4.7 & 35 & 5.1 & 131 & 6.6 \\
\hline Bull (5 to 7 ) & 20 & 2.9 & 21 & 3.0 & 67 & 3.4 \\
\hline Bull (8 to 10$)$ & 5 & 0.7 & 2 & 0.3 & 10 & 0.5 \\
\hline Heifer $^{c}$ (3 to 4) & 73 & 10.6 & 54 & 7.8 & 277 & 14.0 \\
\hline Heifer (5 to 7 ) & 5 & 0.7 & 5 & 0.7 & 26 & 1.3 \\
\hline $\operatorname{Cow}^{d}$ (3 to 4) & 40 & 5.8 & 40 & 5.8 & 49 & 2.5 \\
\hline Cow (5 to 7 ) & 129 & 18.8 & 152 & 21.9 & 423 & 21.4 \\
\hline Cow (8 to 10$)$ & 56 & 8.2 & 71 & 10.2 & 171 & 8.6 \\
\hline Cow $(>10)$ & 7 & 1.0 & 9 & 1.3 & 59 & 3.0 \\
\hline Draught ${ }^{e}$ male $(>4)$ & 0 & 0.0 & 1 & 0.1 & 14 & 0.7 \\
\hline Sub-total females & 466 & 67.8 & 462 & 66.6 & 1,406 & 71.1 \\
\hline Sub-total males & 221 & 32.2 & 231 & 33.3 & 575 & 29.0 \\
\hline Grand total & 687 & 100.0 & 693 & 100.0 & 1,981 & 100.0 \\
\hline
\end{tabular}

Source: March and June cattle histories

${ }^{\text {a Castrated male }}$

${ }^{\mathrm{b}}$ Entire male

'Sexually mature female that has not had a calf

${ }^{\mathrm{d} S}$ Sexually mature female that has had a calf

ePloughing oxen

${ }^{\mathrm{f}}$ All cattle in the herd in KGR at time of sample

${ }^{9}$ Some cattle in the herd on transhumance therefore could only collect data on the sub-herd left in the KGR

median age of three years and cows with one calf, a median age of five years. The age of first calving was therefore between three and five years.

Focus group discussions indicated that first calving occurs at three to four years old. The proportion of threeto four-year-old females that had calved was 39 and 15\% in the March and June surveys, respectively (Table 5), confirming that most females are older than this when they first calve.

The average number of calves born per cow (calf crop) depends not only on fertility but also on life expectancy. Fulani will keep cows until they are at least eight years old or longer if they are reproductively proficient. To calculate the calf crop of a cow of normal life expectancy, we calculated the average number of calves born to three categories of cows: those six, seven or eight years or older. The average number of calves was 3.2, 3.5

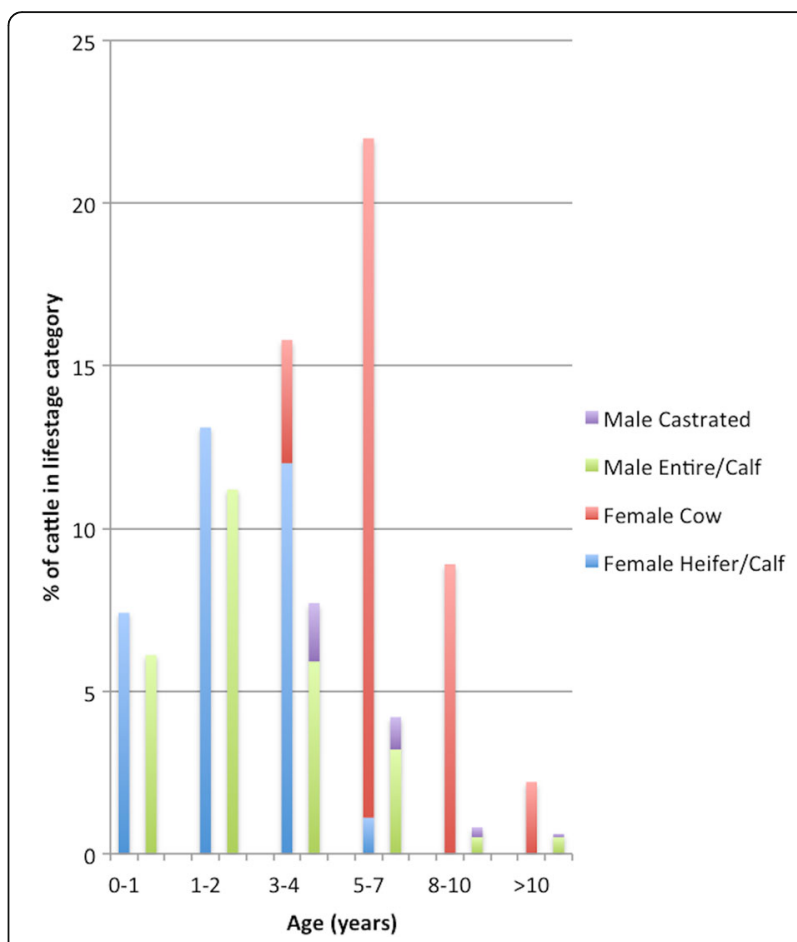

Figure 4 Herd composition by life stage (source: aggregated cattle history data March and June)

and 4.2 for each age category, respectively, from the March interviews and slightly higher for the June interviews when the complete herds were present: $3.4,3.9$ and 4.5, respectively. Thus, a cow will usually produce three to four calves during its lifetime.

The calving interval is generally considered a good index of a cattle herd's reproductive efficiency. However, in extensive African production systems, the wide range in ages at first calving, trade-offs between cow health and frequent calving and a tendency among pastoralists to prolong lactations mean that this is only a partial reflection of efficiency (Mukasa-Mugerwa 1989). Most cows had a calving interval of 16 to 20 months (Figure 5), and the mean and median calving interval in months was found to be 16.0 and 17.1 and 17.6 and 18.0 for the March and June surveys, respectively (Figure 5).

The calving rate was calculated using two denominators: cows (adult females that have calved at least once) and sexually mature heifers and cows, for comparison with rates based on females over three years or more as calculated by Dahl and Hjort (1976). A mean calving rate of 35.5 and $57.2 \%$ was calculated for cows and heifers combined and cows only, respectively.

\section{Entries and exits}

Herd entries (births and purchases) and herd exits (deaths, sales, slaughters and gifts) are summarised in Tables 9 and 10, respectively. The number of households 
Table 6 Selected herd composition data for different regions of Nigeria

\begin{tabular}{|c|c|c|c|c|c|c|c|}
\hline \multirow[t]{3}{*}{ Category } & \multirow{3}{*}{$\begin{array}{l}\text { Age } \\
\text { (years) }\end{array}$} & \multicolumn{6}{|c|}{ Percentage of cattle } \\
\hline & & Fricke 1979 & Pullan 1979 & Blench 1984 & van Raay 1975 & Otchere 1982 & KGR \\
\hline & & Northern Kano & Jos Plateau sedentary ${ }^{a}$ & Mambila Plateau & Zaria & Kaduna plains & $\begin{array}{l}\text { Kachia Grazing } \\
\text { Reserve }\end{array}$ \\
\hline Calf female & $<1$ & 6.0 & 9.5 & 14.1 & 10.1 & 11.4 & 7.4 \\
\hline Heifer & 1 to $3-4$ & 30.6 & 9.0 & 10.7 & 17.5 & 21.1 & 26.2 \\
\hline Adult female & $>3$ to 4 & 38.8 & 45.0 & 32.7 & 40.5 & 32.4 & 35.9 \\
\hline Calf male & $<1$ & 3.7 & 9.5 & 13.8 & 10.1 & 11.4 & 6.1 \\
\hline Immature male & 1 to $3-4$ & 14.2 & 7.0 & 9.3 & 13.4 & 2.8 & 19.0 \\
\hline Adult males & $>3$ to 4 & 6.7 & 20.0 & 19.4 & 8.4 & 20.9 & 5.5 \\
\hline Total & All & 100.0 & 100.0 & 100.0 & 100.0 & 100.0 & 100.0 \\
\hline
\end{tabular}

Source: Amanor (1995) and cited references, with adaptations; KGR. March and June cattle histories

${ }^{a}$ No distinction made between male and female calves, so half allocated to each group

involved in each specific entry/exit category, mean number of cattle entering or exiting per household and the 'rates' of exit and entry were calculated for each entry/ exit category. To calculate these rates, the herd size in June 2010 (i.e. one year previously) was derived by adding herd exits and subtracting entries from the June 2011 composite herd size as defined by the June 2011 questionnaire data. Entry and exit rates were calculated as percentages of the June 2010 herd size.

When considering herd growth across households, Figure 6 shows that a substantial number of households lost more animals than they gained and saw their herd size reduced by 0 to $19 \%$. One household experienced a herd size reduction of more than $50 \%$, losing 10 adults and all five calves born over the course the year and reported having to sell five animals. The herd reduced from 46 to 21 head (Figure 6).

Overall during the course of the year, there was a small net increase in cattle numbers in KGR, from an average per household of 143.1 head to 144.1. The median net increase in livestock holding over the last year was six $(n=16)$ and one $(n=24)$ for new immigrant and old settler households, respectively, and this difference

Table 7 Comparison of herd composition for new immigrant and old settler households

\begin{tabular}{|c|c|c|c|c|c|c|}
\hline \multirow[t]{2}{*}{ Category } & \multirow{2}{*}{$\begin{array}{l}\text { Age } \\
\text { (years) }\end{array}$} & \multicolumn{2}{|c|}{ Number } & \multicolumn{2}{|c|}{ Percent } & \multirow{2}{*}{$\begin{array}{l}\text { Pearson's chi } \\
\text { square }\end{array}$} \\
\hline & & New & Old & New & Old & \\
\hline Calf female & $<1$ & 70 & 60 & 7.1 & 6.0 & $0.867, p=0.352$ \\
\hline Heifer & 1 to $3-4$ & 279 & 269 & 28.2 & 27.1 & $0.311, p=0.577$ \\
\hline Adult females & $>3$ to 4 & 348 & 380 & 35.2 & 38.3 & $2.024, p=0.155$ \\
\hline Calf male & $<1$ & 50 & 75 & 5.1 & 7.6 & $5.229, p=0.022^{a}$ \\
\hline Immature male & 1 to $3-4$ & 174 & 163 & 17.6 & 16.4 & $0.488, p=0.485$ \\
\hline Adult males & $>3$ to 4 & 68 & 45 & 6.9 & 4.5 & $5.063, p=0.024^{a}$ \\
\hline Grand total & & 989 & 992 & 100 & 100 & \\
\hline
\end{tabular}

Source: June cattle histories

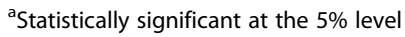

was found to be statistically significant at the $10 \%$ level (Kruskal-Wallis, $H=2.75, \mathrm{DF}=1, p=0.0976$ ).

Average herd percentage increase (current herd size minus herd size one year ago divided by herd size one year ago) was $2.2 \%$. Mean herd percentage increase for new immigrant households was $5.0 \%$ ( -2.8 to $12.7 \%$, 95\% confidence interval $(\mathrm{CI}))$, higher than the $0.4 \%(-6.0$ to $6.7 \%, 95 \% \mathrm{CI}$ ) increase for old settler households.

Reasons for adult mortality were as follows: $63.6 \%$ disease, $12.1 \%$ trauma (falling in pits or drowning in rivers), $6.1 \%$ starvation and $15.2 \%$ were killed during outbreaks of communal violence. Reasons for slaughter were the following: weddings (15.0\%), the Eid religious festivals (20.0\%), home consumption (30.0\%) and naming ceremonies (35.0\%). As stated in a focus group discussion: 'Fulani do not have much of a taste for meat' and this was reflected in the low slaughter rate $(0.6 \%)$; most animals slaughtered $(73.0 \%)$ were young males.

Two types of gift giving were practised in the KGR: zakat (or alms giving, one of the five pillars of Islam) is the donation of cattle to non-family members at designated times of the year, whereas gift giving to family members is practised any time to help the member of a kinship group in need of assistance. Zakat accounts for $75.0 \%$ of all gift giving and gifts to relatives, $25.0 \%$. The Fulani interpretation of the zakat is for one young male or female to be given away for every 40 adult cattle owned. Sixteen households out of the 40 engaged in gift giving, but the number of animals given as gifts for zakat did not consistently follow the rule, with some households giving more cattle (and others less) than their herd size would dictate.

Most cattle were sold for everyday cash needs (40.8\%) and to cover school fees $(22.4 \%)$. Other reasons for sale of animals included the following: removal of old unproductive animals (1.3\%), to pay for hajj pilgrimage (1.3\%), naming ceremonies $(2.7 \%)$, for 
Table 8 Number of calves per adult female

\begin{tabular}{|c|c|c|c|c|c|c|c|c|c|}
\hline \multirow[t]{2}{*}{ Survey } & & \multicolumn{7}{|c|}{ Number of calves given birth to } & \multirow[b]{2}{*}{ Total } \\
\hline & & 0 & 1 & 2 & 3 & 4 & 5 & 6 to 10 & \\
\hline \multirow[t]{5}{*}{ March } & No. females $>3$ years & 142 & 119 & 119 & 107 & 66 & 25 & 14 & 592 \\
\hline & $\%$ of total cows & 24.0 & 20.1 & 20.1 & 18.1 & 11.1 & 4.2 & 2.4 & 100.0 \\
\hline & Mean age (years) & 3.5 & 5.1 & 5.7 & 6.8 & 7.8 & 9.4 & 12.3 & \\
\hline & s.d. age (years) & 0.7 & 1.4 & 1.2 & 1.3 & 1.4 & 1.7 & 4.9 & \\
\hline & Median age (years) & 3 & 5 & 6 & 7 & 8 & 9 & 10 & \\
\hline \multirow[t]{5}{*}{ June } & No. females $>3$ years & 302 & 180 & 181 & 136 & 78 & 73 & 46 & 996 \\
\hline & $\%$ of total cows & 30.3 & 18.1 & 18.2 & 13.7 & 7.8 & 7.3 & 4.6 & 100.0 \\
\hline & Mean age (years) & 3.5 & 5.1 & 6.0 & 7.2 & 8.2 & 9.7 & 11.8 & \\
\hline & s.d. age (years) & 0.7 & 0.8 & 1.1 & 1.2 & 1.8 & 2.1 & 2.5 & \\
\hline & Median age (years) & 3 & 5 & 6 & 7 & 8 & 9 & 12 & \\
\hline
\end{tabular}

Source: March and June cattle histories

new immigrants to cover the cost of the move to the KGR (2.7\%), health/hospital costs (3.9\%), building costs for home improvements (3.9\%), weddings (9.2\%) and animal health costs such as vet fees and drugs (11.8\%). Almost half of the households (19/40) sell 6 to $10 \%$ of their stock a year. The category of animals most frequently sold was young males, although young and mature females, including old unproductive cows, were also sold (Table 11).

Focus group discussions in June confirmed that KGR households sell both male and female animals, anywhere from one to seven years old. A statement from a cattle trader echoed the sentiments of the unusual sale practices in KGR:

Usually most common is for people to sell bulls of 5 to 7 years and selling of females is only when very necessary, but in KGR it has been different with people selling male and female animals of 2-3 years because of cash needs which cannot be met by selling milk.

The sale rate (animals sold as a proportion of herd size) was $7.6 \%$ for new immigrant households as compared to $10.9 \%$ for old settlers, and this difference was found to be statistically significant at the $5 \%$ level (Kruskal-Wallis, $H=4.54, \mathrm{DF}=1, p=0.0313$ ).

The discussions also indicated that in the KGR more animals are sold during the rainy season, as fewer people are away on transhumance. The reason for this was explained by a young focus group discussant:

There are more cash needs during the wet season as activities are greater and more people are around as everyone has come back from transhumance. For example, people need to buy fertiliser for their crops and drugs for their cattle because of samore [trypanosomiasis]

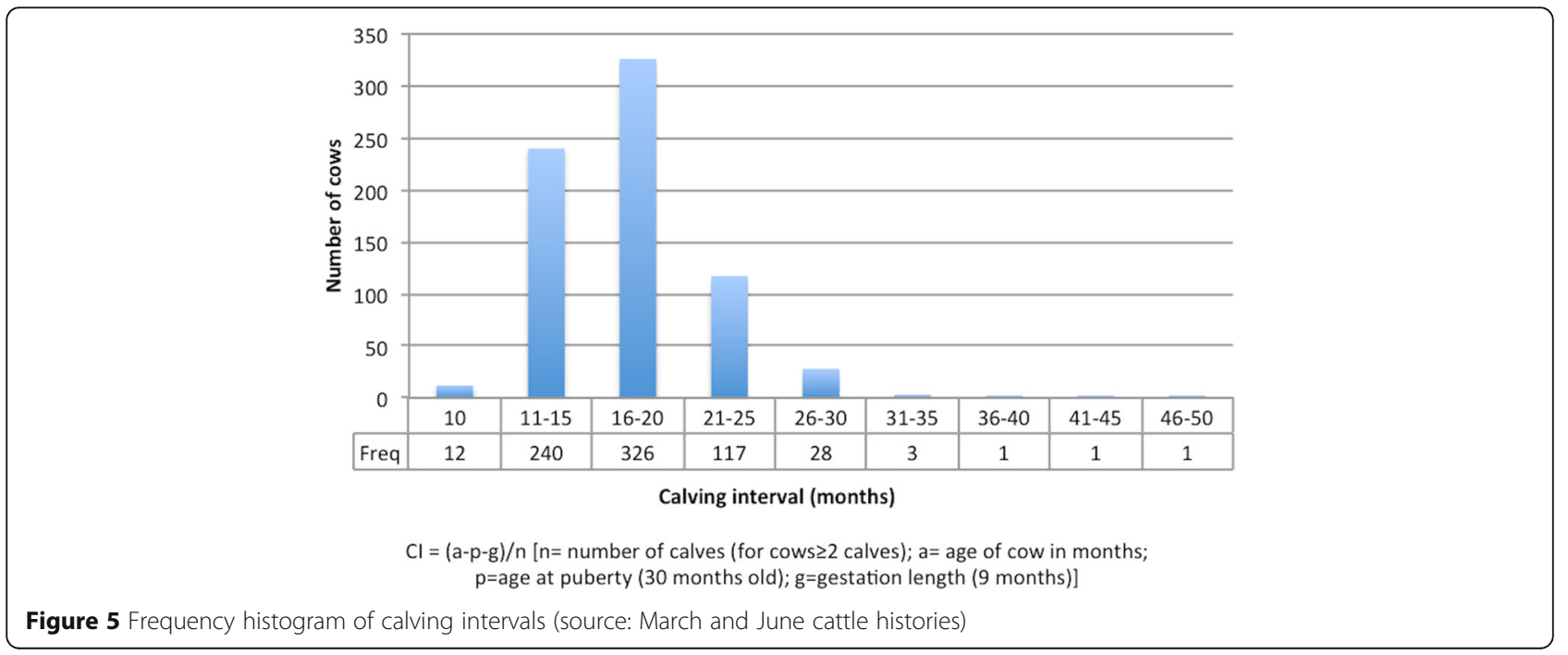


Table 9 Breakdown of herd entries by cause

\begin{tabular}{|c|c|c|c|}
\hline & \multicolumn{2}{|l|}{ Entries } & \multirow[b]{2}{*}{ Overall } \\
\hline & Births & Purchases & \\
\hline No. $\mathrm{HH}$ (\% of $\mathrm{HH})$ & $39 / 40$ & $20 / 40$ & $40 / 40$ \\
\hline No. cattle & 1,055 & 76 & 1,131 \\
\hline$\%$ of all entries & 93.3 & 6.7 & 100.0 \\
\hline \multirow[t]{2}{*}{ Mean no./HH } & 26.4 & 1.9 & 28.7 \\
\hline & Calving rate & Purchase rate & Entry rate \\
\hline Denominator & Cows & All & All \\
\hline Number cattle & 1,845 & 5,722 & 5,722 \\
\hline Rate (\%) & 57.2 & 1.3 & 19.8 \\
\hline
\end{tabular}

and hanta [clostridial disease], and people need to sell animals to buy food for people in the house.

Most animals purchased were young males and females (Table 11).

It was explained that the KGR community recognises two main issues impacting on productivity and revenue derived from the sale of cattle, summed up in this statement from a focus group participant:

There are two restrictions on animal productivity here: grazing and disease and the two issues play their own role. Limited availability of grazing impacts on calving rates and growth rates. Disease results in high mortality and poor body condition of animals which results in low pricing.

\section{Future of pastoralism}

Focus group discussions on the future of pastoralism revealed that almost all KGR community members shared pessimism about the future of their pastoral system as it currently exists. Two main issues were raised; the unsustainability of transhumance (an issue they expressed as linked to competition for land and conflict) and the necessity for pastoralists to start diversifying their livelihoods by embracing crop farming and fodder banking.

Two key informant interviews with elite community members capture this shared vision particularly eloquently. An elderly Ardo (chief) from KGR stated during a key informant interview on what the future holds for his children:

I want my children to live a life where they can grow enough to support their animals during the dry season. There is no future in sending animals into the wilderness. The future for nomadic style pastoralism is bleak. If we do not learn how to grow crops for our own consumption and forage, the big farmers with big farms will remain only and nomads will be boxed out of their livelihoods.

His sentiments were echoed by the President of the Dairy Bull Cooperative of the KGR:

Our transhumant system as we know it is going to face a lot of problems. The livestock population is increasing whilst the graze-able land is decreasing, which encourages competition of crop farmers with pastoralists. The crises are forcing Fulani to migrate to crisis-free areas. We used to have abundant grasses but as a result of the crises there is more migration of people and increases in the population of the grazing reserve. This has resulted in an increased population density of livestock per graze-able areas. If this continues, pastoralism and nomadism will have to stop. Agreeing to stop transhumance will take a long time, as most movements are to look for greener pasture otherwise our animals would starve.

Table 10 Breakdown of herd exits by cause

\begin{tabular}{|c|c|c|c|c|c|c|c|}
\hline & \multicolumn{6}{|l|}{ Exits } & \multirow[b]{2}{*}{ Overall } \\
\hline & Calf deaths & Non-calf deaths & Sale & Slaughter & Gifts & Offtake & \\
\hline $\mathrm{No} . \mathrm{HH}$ & $26 / 40$ & $26 / 40$ & $39 / 40$ & $15 / 40$ & $16 / 40$ & $39 / 40$ & $40 / 40$ \\
\hline No. cattle & 142 & 363 & 500 & 37 & 63 & 600 & 1,105 \\
\hline$\%$ of all exits & 12.9 & 32.9 & 45.2 & 3.3 & 5.7 & 54.3 & 100.0 \\
\hline \multirow[t]{2}{*}{ Mean no./HH } & 3.6 & 9.1 & 12.5 & 0.9 & 1.6 & 15 & 27.6 \\
\hline & Calf death rate & Non-calf death rate & Sale rate & Slaughter rate & Gift rate & Offtake rate & Exit rate \\
\hline Denominator & Calves & Non-calves & All & All & All & All & All \\
\hline No. cattle & 1,070 & 4,652 & 5,722 & 5,722 & 5,722 & 5,722 & 5,722 \\
\hline Rate (\%) & 13.3 & 7.8 & 8.7 & 0.6 & 1.1 & 10.5 & 19.3 \\
\hline
\end{tabular}

Source: June questionnaire; all rates based on herd size one year previously 


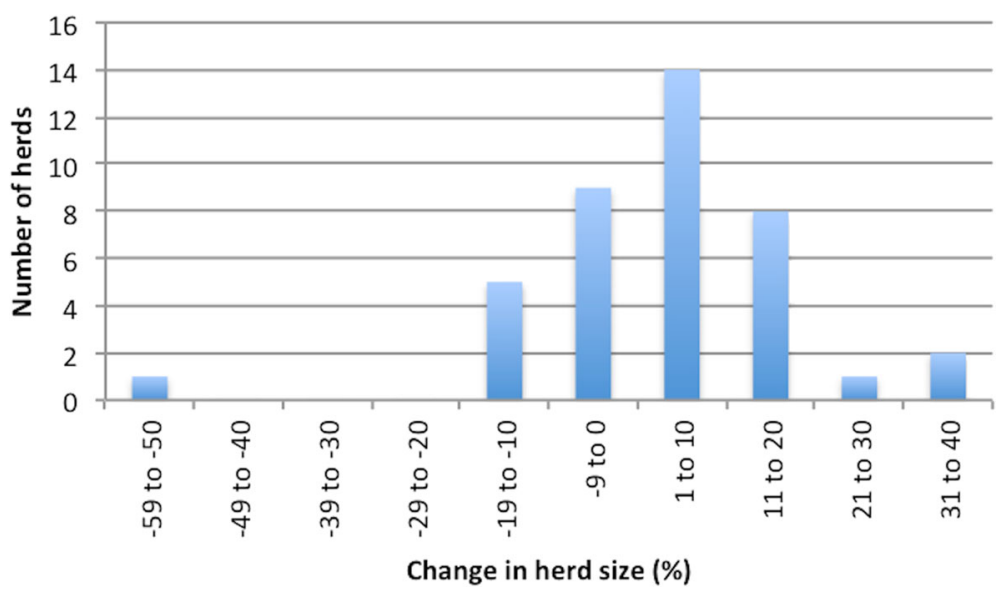

Figure 6 Changes in herd size over one year (source: June questionnaire)

The community vision of a better future was centred on pastoralists developing the skills and expertise to grow fodder, as an alternative to transhumance. This was inexorably linked to land ownership issues, with most discussants emphasising that until Fulani are given rights to land, their future remains uncertain. There was also a recognition that livestock production needs to intensify and integrate with crop farming.

The following request from a focus group discussant illustrates the importance of the issue of fodder:

One year the dry season was so prolonged that our animals were suffering of hunger, and this initiated this idea of fodder banking. We would like you to invite research persons to enlighten us on the issue of fodder banking, so that we may make hay and curtail the suffering of the dry season.

On the issue of intensification, this discussant stated that:

From now to 20 years on, pastoralists will need to change their primitive extensive system to an intensive system. But to do this the Fulani man needs to have vast and demarcated land for intensive breeding.

Table 11 Age and sex distribution of cattle sold or purchased

\begin{tabular}{llllllll}
\hline & \multicolumn{2}{l}{ Cattle sold \% } & & \multicolumn{3}{l}{ Cattle purchased \% } \\
\cline { 2 - 3 } & Young & Mature & Total & & Young & Mature & Total \\
\hline Male & 30.2 & 23.0 & 53.2 & & 50.0 & 2.6 & 52.7 \\
Female & 18.6 & 28.2 & 46.8 & & 43.4 & 3.9 & 47.3 \\
Total & 48.8 & 51.2 & 100 & & 93.4 & 6.5 & 100.0 \\
\hline
\end{tabular}

Source: June questionnaire
The important issue of land ownership was also captured by the President of the Dairy Bull Cooperative in his vision for a better future:

I appeal to the government to let there be grazing reserves like the KGR in all states of Nigeria. This will go a long way to curtailing the farmerpastoralist conflict. KGR has never had a crisis, as there is no competition with native men unlike in other states. The grazing reserves, apart from helping to solve the problems of the crises, have the added advantage of giving the Fulani man a right to ownership. Let the Fulani man have land that he owns.

\section{Discussion}

Population growth and expansion of agriculture has been presented as the beginning of the end of pastoralism in Africa (Baxter 2001; Hogg 1986; Markakis and Minority Rights Group International 2004) and more specifically in West Africa and Nigeria (Mortimore and Adams 1998). The challenges facing pastoralism are not new; in 1975, van Raay reported 'worsening conditions'. The grazing reserves established during the 1960s in Nigeria were an attempt to provide the Fulani with secure land tenure and to modernise the livestock sector, away from traditional practices of cattle transhumance. Emphasis was placed on settlement or 'sedentarisation' of nomadic pastoralists with a view to reducing mobility of both people and their livestock and opportunities for farmer-pastoralist encounters (Suleiman 1986).

Despite the widespread perception that Fulani pastoralists living within grazing reserves are becoming increasingly sedentary, the inhabitants of the KGR have continued to practise wide-ranging transhumance driven by the limited availability of grazing, similar to that of Fulani elsewhere. This study provides evidence of the 
challenges facing Fulani pastoralists living in grazing reserves in Nigeria. These stresses included political upheaval, a lack of outlet for milk, poor grazing conditions and overcrowding. Despite these stresses, the inhabitants of KGR have maintained the majority of their pastoralist cattle keeping practices and grazing reserves have not curtailed the transhumant habits of their Fulani inhabitants. While some households keep their cattle all year within KGR, a significant proportion take some or all of their herd on transhumance in the dry season and, with the arrival of the new immigrants and the ensuing competition for grazing, the wet season.

The land provided within the grazing reserve is too limited in area and quality to meet the nutritional needs of the cattle population dependent on it. Poor grazing during the dry season and competition for the grazing during the wet season are the main motivations for transhumance as observed outside of the reserves. A recent survey on the Jos Plateau showed that $10 \%$ of villages practise transhumance in the dry season, $17 \%$ in the wet season and $47 \%$ in both seasons with only $26 \%$ not practising transhumance (Majekodunmi et al. 2013).

Considerable efforts were made to encourage Fulani to settle during the 1980s including building an administrative headquarters, roads, dams and cattle dips. The NLPU and ILCA developed a farmer centre, credit scheme, veterinary services, bore wells, experimented with pasture improvement and developed a smallholder dairy scheme supplying supplementary cattle feed on credit. The programme, supported by the World Bank, supported 24 staff (Oxby 1984), but on cessation of funding, none of the amenities and services were maintained and staff numbers were reduced to a single Project Officer. Furthermore, originally, those wishing to bring animals into the reserve had to obtain a permit specifying the number and type of animals and where they were to graze, but today, access is now effectively unregulated. While permitting access for the 250 families who moved to the KGR in May 2011 to flee from inter-communal violence, this mass influx was a major driver for increased frequency, duration and proportion of the herd taken on transhumance, due to increased competition for grazing within the KGR, as shown by focus group and questionnaire data (Figure 2, Tables 3 and 4).

Cattle play a major cultural role in pastoral communities, and unproductive animals may be hoarded for both prestige and sentimental reasons. The acquisition of stock and its wellbeing has been described as a means in itself rather than a means to an end (van Raay 1975). This strong affinity for cattle, the 'cattle complex', is 'a strong attachment for cattle, manifested in love for and identification with the animals and in dislike of killing them except in a ritual context' (Herskovits 1952).
However, herd modelling indicates that herd survival in times of drought depends on herd size being maximised in times of plenty (Dahl and Hjort 1976).

Cattle practices have changed little within the grazing reserve: pastoral households traditionally elect to split cattle into one subsistence herd and one or several reserve herds (Dahl and Hjort 1976; Jabbar et al. 1995), and herd numbers fluctuate over time from division or re-grouping of herds and sub-herds. In this study, triangulation of different source data was effective in teasing out herd estimates for the ruga (homestead) and the wuro (extended household). An important factor to consider was those cattle owned by the wuro that were kept on other holdings outside of the KGR (Table 2).

The slightly higher overall percentage of female than male calves in herds within KGR was suggestive of higher survival of female calves, a pattern that persists for juvenile cattle (one to two years old) (Table 5, Figure 3). Fulani herds are reported to favour female over male calves with females being given preference to suckle, achieving better nutrition (Coulomb et al. 1980; Dahl and Hjort 1976; Wagenaar et al. 1986).

The majority of herds in the KGR comprise 70 to $80 \%$ females and 20 to $30 \%$ males. The sex ratio is comparable to that on the Jos Plateau (Majekodunmi et al. 2014) and that reported by van Raay (1975). The number of male cattle was observed to decline as animals reached maturity, with females over two years old making up more than half of the herd. Most bulls exit the herd before four years of age, and from seven years, the body condition of steers was observed to deteriorate. After eight years of age, the number of females was also observed to decline. A few older animals of low market value were retained including female animals of 10 years or older, lending support to the arguments outlined above about maintaining large herds (Table 5, Figure 3).

This herd composition is typical of pastoralists who bias herds towards reproductive animals for herd growth and milk production (subsistence and sale), although the customer base for milk products is limited in KGR. The lower percentage of mature males in KGR than reported in other studies in Nigeria may reflect the need for KGR households to sell male cattle before maturity when cash cannot be obtained from sale of milk (Table 6).

This hypothesis was corroborated by data presented in Table 7, which showed that old settler households had a higher overall percentage of male calves but a lower overall percentage of bulls. This could be due to old settler households favouring survival of male calves over female calves through better access to suckling, highlighting a need to generate cash through sale of male stock. The lower percentage of bulls confirms that more immature males exited the herd in old settler households than in new immigrant households to meet cash 
needs, and fits with the sale data, which shows a higher percentage sale of cattle by old settler than new immigrant households.

Mean sales of cattle in the KGR, at $8.7 \%$ of the herd, were higher than previously reported: $3.6 \%$ (Wagenaar et al. 1986) and 3.2\% (Majekodunmi et al. 2014), but were similar to figures described in the 1980s for the Jos Plateau (Pullan and Grindle 1980). The amount received per animal sold in KGR is low at 334 USD (compared to 681 USD received by Fulani on the Jos Plateau in the same year; value corresponds to average price obtained across homogenous categories of cattle). KGR residents are isolated from cattle markets and often have to accept lower prices from buyers who come to the farm gate. The cost of living in KGR is high due to remote location and poor access. Transportation costs are high; $500 \mathrm{ml}$ 'pure water' sold at twice the price in KGR (10 Naira as compared to 5 Naira across Nigeria). Generators are the sole source of electricity, so people pay a premium for services that demand electricity such as grinding their corn and charging mobile phones.

Deciding which animal to sell is dependent on herd size, species composition, age and sex structure and how much cash is needed. Small cash needs are often met by selling small ruminants while cattle are sold when larger sums are required, e.g. to replenish grain stock, for weddings or other important festivities (Sutter 1987). Households tend to preferentially sell non-productive elements of their herds. Market records in northern Nigeria/subhumid zone indicated that 70 to $88 \%$ of all sales were older males (Fricke 1979; Amanor 1995). Older females at the end of their breeding life also usually account for a significant proportion of sales and/or slaughters, often occurring in more local markets; thus, the $28.2 \%$ share of farm gate sales recorded in this study (Table 11) is not untypical nor is the sale of young males $(30.2 \%$ of sales). More young males than mature males were sold, perhaps reflecting grazing constraints. However, the high offtake rate of heifers is very unusual (18.6\% of all sales), as this compromises the future growth of the herd (Abaelu 1973; Pullan and Grindle 1980; Sieff 1995).

It is likely that the Fulani of the KGR have developed a breeding strategy which focuses on the breeding of some heifers for sale and of males as fat-stock but in which milk is not an important cash resource. Elsewhere, this has been described as 'a variant of specialised milking strategies' (Amanor 1995): the example of a study undertaken by Fricke (1979) is cited where the majority of stock were sold young, between the ages of two and three, with up to $15 \%$ of total sales consisting of heifers. The isolation of KGR from other non-pastoralist communities, and responses during focus group discussions, indicate that there is only a small market for dairy products, due to the distance to be travelled on foot to sell these products. KGR households are reliant on young stock sales to generate cash, to compensate for the absence of a milk market.

Reproductive performance in KGR was consistent with that previously reported for traditionally managed White Fulani cattle. The mean calving rate in KGR was $57 \%$, in line with that for Fulani herds in northern Nigeria (Blench 1984; Otchere 1982). The mean calving rate based on cows and heifers (aged three to four combined) was $36 \%$, equal to that previously observed (Pullan 1979; Majekodunmi et al. 2014). The mean calving interval of 17.4 months implies a calving rate of $69 \%$, for KGR herds, in agreement with a calving interval of 14 to 18 months reported for White Fulani cattle (Oyedipe et al. 1982).

The age at first calving in KGR is between three and five years, consistent with the 4.75 years reported in Zaria (Akpa et al. 2012). An average age of 3.3 years was previously reported for White Fulani cattle in Northern Nigeria (Joshi et al. 1957). KGR cows birth an average of three to four calves during a reproductive lifetime, in line with the figure reported by Demiruren (1974). Other authors have reported between four and seven calves (Grunnet 1962). Some cows in KGR had produced a calf crop of 10, while other cows six years and over had only given birth to a single calf. Nutrition impacts on fertility and is directly related to the availability of grazing. Low productivity may reflect over-stocking and lack of grazing in the KGR.

A small proportion of males are castrated at three to four years old (Figure 4), mostly to avoid boisterous behaviour upon reaching sexual maturity. Male castrates are also reported to keep the cows calm. These animals are also used for draught power, at low levels, across the KGR.

The average calf mortality rate in KGR was $13.3 \%$, similar to that observed in the Jos Plateau (Majekodunmi et al. 2014) and figures of 10 to $15 \%$ recorded by Demiruren (1974) and Williamson and Payne (1965). The calf mortality rate was significantly higher than that observed in adults indicating that disease and/or under-nutrition in the first year of life impacts on herd productivity. The average mortality in adults (7.8\%) was twice as high as that recorded by Majekodunmi et al. (2014) for cattle maintained on the Jos Plateau, similar to the $8.1 \%$ previously recorded by Pullan and Grindle (1980). While nutrition and livestock disease remain important constraints to productivity in KGR, $15.2 \%$ of herd deaths were caused by shootings during the post-election violence of April to May 2011.

Reciprocal assistance, a key component for survival of pastoral communities, is still practised in the agropastoralist community of KGR. The gift rate is 
approximately double that of the slaughter rate for all households. That not all households chose to engage in zakat may indicate that diversification into agriculture has pushed households towards individualistic behaviour (Bonfiglioli 1993).

The purchase rate of cattle in KGR at $1.3 \%$ was similar to that previously reported (Majekodunmi et al. 2014; Pullan and Grindle 1980). Most purchased animals were young, with more males than females being purchased. Households in KGR frequently bought young males as breeding bulls to improve the genetic diversity of their herds, which is unusual since Fulani typically purchase young females to improve herd reproductive capacity.

Overall during the course of the year, there was a small net increase in cattle numbers in KGR, from an average per household of 143.1 head to 144.1 . New immigrants recorded a statistically significant higher herd net growth in the year prior to their arrival in the KGR than old settlers. Thus, cattle productivity in KGR is sufficient to support Fulani households by maintaining current herd wealth, but low productivity is a cause for concern.

While providing a key role in providing security in times of conflict, grazing reserves are failing to meet their primary objectives of promoting sedentarisation, intensification and self-sufficiency and reducing conflict between crop and cattle keepers. However, from the inception, these objectives were those set by government planners and not necessarily geared to the livestock management practices and requirements of the Fulani pastoralists, and the passage of time has made the objectives even more difficult to achieve.

There is a gross mismatch between the needs of the resident cattle population and the availability of grazing. Agricultural expansion into grazing lands means that livestock can no longer subsist on natural forage alone. The long-term solution may mean the intensification of livestock production and integration of agricultural systems, i.e. feeding cattle with farm-produced fodder (Mortimore and Adams 1998), as indicated by the pastoralists themselves in focus group discussions. However, programmes to supply fodder in the dry season (WatersBayer and Taylor-Powell 1984b; 1984a) failed to induce self-sufficiency within KGR. This study shows that despite the desires of its inhabitants, KGR is failing to promote this shift from extensive to a more productive intensive and integrated farming; there is insufficient land available per household to enable integration of crop farming for production of fodder on a scale sufficient to meet current herd needs, compounded by the arrival of new households.

Moritz et al. (2009) considered pastoral systems were not in crisis but had found successful adaptations to changing circumstances: movement to sub-humid zones, intensification of livestock production and its integration into agricultural systems. Similarly within KGR, productivity is being maintained by successful adaptations to local conditions such as lack of an outlet for milk and increasing competition for grazing due to influx driven by conflict; adaptations are through selling females and young stock, herd splitting and higher frequency and duration of transhumance during periods of population pressure.

While this study has shown that pastoralists of the KGR are not yet at breaking point, focus group discussions indicated that the community feels it is coming under increasing pressure from agricultural expansion and conflict-driven influx of refugees. In addition, the numbers of cattle kept by non-Fulani villagers and in peri-urban intensive/commercial livestock farms have risen steadily. In particular, the urban/peri-urban sector has expanded over the past 25 years as investment in agriculture in Nigeria has increased (Resource Inventory and Management 1992), and these producers are now directly competing with Fulani for their livelihoods.

\section{Conclusions}

These findings offer a snapshot view of cattle management and productivity within the Kachia Grazing Reserve, advancing a contemporary understanding of pastoralism in Nigeria today. This case study, conducted before and after a period of mass immigration as a result of post-election violence and internal displacement of Fulani families, indicates a key role for grazing reserves as safe havens, protecting Fulani and their cattle from civil strife and violent clashes but highlights the pressure that local immigration generates within communities. The KGR community undertakes transhumance and herd splitting in response to limited availability of grazing within the reserve, and transhumance was found to increase in duration and frequency with the arrival of the new immigrants.

The broad similarity between the herd composition and productivity parameter results obtained in this study with those previously cited in the literature indicates that fundamental management practices and productivity have remained relatively unchanged over the last 40 years.

The preponderance of mature females in the herds is indicative of a breeding strategy, geared towards milk production for home consumption and sale. However, there is no commercial market for milk so that the herd management strategy is more probably geared towards producing sufficient young animals for sale although this means sacrificing future herd growth and 
production. This was confirmed by the statistically significant differences between new immigrants and old settlers in sale rates and in the proportion of adult males kept, with old settlers selling a higher proportion of their immature male and female stock. These differences are confirmed by the finding that the average herd growth rate, which referred to the year 2010 to 2011, prior to the immigrants' move into KGR, was significantly lower in old settler as compared to new immigrant households.

Given the current climate of political instability, the societal and political pressure for transhumance to cease and the lack of investment in providing sufficient land, infrastructure and market access to support the evolution of grazing reserves, the future of pastoralism as it currently exists seems uncertain, a position emphasised by the inhabitants of KGR who are concerned for their way of life.

\section{Abbreviations}

Cl: Confidence interval; HH: Household; ILCA: International Livestock Centre for Africa; KGR: Kachia Grazing Reserve; NLPU: National Livestock Project Unit; USD: US dollar

\section{Acknowledgements}

The assistance of Dr. Igweh from the Nigerian Institute for Trypanosomiasis Research (Vom) is gratefully acknowledged. We extend our thanks to Prof. Ian Maudlin for his editing of the manuscript.

\section{Funding}

This work was supported by the UK's Biotechnology and Biological Sciences Research Council (BBSRC) under the 'Combating Infectious Diseases in Livestock for International Development' (CIDLID) scheme and the European Union's Seventh Framework Program (FP7/2007-2013) under grant agreement no 221948, ICONZ (Integrated Control of Neglected Zoonoses).

\section{Authors' contributions}

MJD, SCW, APMS, RAO and AOM designed the study. MJD, UBM, WJB and AMG undertook the fieldwork. MJD analysed the data and drafted the original manuscript with input from AOM, APMS, SCW and HB. WB produced the maps. All authors read and approved the final manuscript.

\section{Authors' information}

MJD is a veterinarian and epidemiologist at the University of Edinburgh (UoE) with an interest in zoonotic disease control. AOM is an epidemiologist and postdoctoral researcher at the (UoE) at the time of the study, now working at University of Ghana. APMS is a livestock and health economist. WJB, AMG and RAO are veterinarians and brucellosis researchers at NVRI. $\mathrm{HB}$ is a junior livestock researcher in Ghana. UBM is a trypanosomiasis researcher at NITR. WB is a geographical information system specialist. SCW is a Professor of Medical and Veterinary Molecular Epidemiology and is group leader of the Neglected Zoonoses research group at UoE.

\section{Competing interests}

The authors declare that they have no competing interests.

\section{Ethics approval and consent to participate}

The study was undertaken under the auspices of the National Veterinary Research Institute (Nigeria). Ethical clearance for sampling of animals and interviewing of human subjects was granted on 7 February 2011 by the Ministry of Health, Kaduna State (Nota MOH/HS/PER/VOL.I/234/70). All study participants were briefed on the purpose of the study, and informed consent was obtained.

\section{Author details}

'Division of Infection and Pathway Medicine, School of Biomedical Sciences, College of Medicine and Veterinary Medicine, The University of Edinburgh, Chancellor's Building, 49 Little France Crescent, Edinburgh EH16 4SB, UK. ${ }^{2}$ Livestock and Poultry Research Centre, College of Basic and Applied Sciences, University of Ghana, P. O. Box LG 38, Accra, Ghana. ${ }^{3}$ Avia-GIS, Risschotlei 33, B-2980 Zoersel, Belgium. ${ }^{4}$ Nigerian Institute for Trypanosomiasis Research, No 1 Surame Road, Ungwan Rimi G.R.A., P.M.B, 2077 Kaduna, Nigeria. ${ }^{5}$ Brucellosis Research Unit, Bacterial Research Division, National Veterinary Research Institute, P.M.B. 01, Vom, Plateau State 930001, Nigeria.

Received: 6 May 2016 Accepted: 1 November 2016

Published online: 01 December 2016

\section{References}

Abaelu, J.N. 1973. Economics of livestock production in Nigeria. Proceedings of the Agricultural Society of Nigeria 10: 33-39.

Akpa, G.N., C. Alphonsus, and A. Abdulkareem. 2012. Evaluation of herd structure of white Fulani cattle holdings in Zaria, Nigeria. Scientific Research and Essays 7(42): $3605-3608$

Alausa, O.K., and A. Awoseyi. 1976. Brucellosis: The situation in Western Nigeria. Tropical and Geographical Medicine 28: 54-59.

Amanor, K.S. 1995. Dynamics of herd structures and herding strategies in West Africa: A study of market integration and ecological adaptation. Africa 65(3): 351-394.

Awogbade, M.O. 1987. Grazing reserves in Nigeria. Commission on Nomadic Peoples 23: 18-30.

Azuwike, O.D., and E. Enwerem. 2010. Nigeria's changing environment and pastoral nomadism: Redistribution of pains and gains. Berlin: Free University of Berlin. http://www.diss.fu-berlin.de/docs/servlets/MCRFileNodeServlet/FUDOCS derivate_000000001383/Azuwike-NIGERIAS_CHANGING_ENVIRONMENT_ AND_PASTORAL_NOMADISM-329.pdf. Accessed 20 Oct 2016.

Baxter, P.T.W. 2001. Immediate problems: A view from a distance. In African pastoralism: Conflict, institutions and government, ed. M.A.M. Salih, T. Dietz, and A.G.M. Ahmed. London: Pluto.

Bennett, S., T. Woods, W.M. Liyanage, and D.L. Smith. 1991. A simplified general method for cluster-sample surveys of health in developing countries. World Health Statistics Quarterly 44(3): 98-106.

Blench, R. 1984. Livestock and land use in Southern Gongola State, Nigeria. Volume II. Main text. Oxford: Resources Inventory and Management (RIM).

Blench, R. 1996. Aspects of resource conflict in semi-arid Africa. Overseas Development Institute (ODI) Natural Resource Perspectives no. 16. London: ODI. https://www.odi.org/sites/odi.org.uk/files/odi-assets/publicationsopinion-files/2959.pdf. Accessed 20 Oct 2016.

Bonfiglioli, A.M. 1993. Agro-pastoralism in Chad as a strategy for survival; an essay on the relationship between anthropology and statistics. World Bank Technical Paper no 21. Washington: World Bank.

Bourn, D., R. Reid, D. Rogers, B. Snow, and W. Wint. 2001. Environmental change and the autonomous control of tsetse and trypanosomosis in sub-Saharan Africa. Review commissioned by UK Department of International Development's Rural Livelihoods Animal Health Programme. Oxford: Environmental Research Group Oxford.

Catley, A. 2006. Use of participatory epidemiology to compare the clinical veterinary knowledge of pastoralists and veterinarians in East Africa. Tropical Animal Health and Production 38(3): 171-184.

Catley, A., R.G. Alders, and J.L. Wood. 2012. Participatory epidemiology: approaches, methods, experiences. Veterinary Journal 191(2): 151-160. doi:10.1016/j.tvjl.2011.03.010

Chambers, R. 1994. The origins and practice of participatory rural appraisal. World Development 22(7): 953-969. doi:10.1016/0305-750X(94)90141-4.

Coulomb, J., H. Serres, and G. Tacher. 1980. L'Elevage en pays saheliens. Paris: Presses Universitaires de France.

Dahl, G., and A. Hjort. 1976. Having herds: Pastoral herd growth and household economy. Stockholm studies in social anthropology. Stockholm: University of Stockholm.

Demiruren, A.S. 1974. The improvement of nomadic and transhumant animal production systems. Rome: FAO.

Ducrotoy, M.J. 2015. Livelihoods of Fulani pastoralists and burden of bacterial zoonoses in the Kachia grazing reserve, Nigeria. PhD Thesis, University of Edinburgh. 
Fricke, W. 1979. Cattle husbandry in Nigeria: A study of its ecological conditions and social-geographical differentiations. In Heidelberger Geographischen Arbeiten. Heidelberg: Geographisches Institut der Universitaet.

Grunnet, N.T. 1962. An ethnographic-ecological survey of the relationships between the Dinka and their cattle. Folk 4: 5-20.

Herskovits, M.J. 1952. Economic anthropology: A study in comparative economics. New York: Knopf.

Hogg, R. 1986. The new pastoralism: Poverty and dependency in northern Kenya. Africa 56: 319-33.

Ingawa, S.A., G. Tarawali, and R. von Kaufmann. 1989. Grazing reserves in Nigeria: Problems, prospects and policy implications. African Livestock Policy Analysis Network Paper No. 22. Addis Ababa: ILCA.

Integrated Regional Information Networks (IRIN). 2009a. Nigeria: Government steps in to curb farmer-nomad clashes. Humanitarian news and analysis

Integrated Regional Information Networks (IRIN). 2009b. Nigeria: Impunity for perpetrators of sectarian violence. Humanitarian news and analysis

Integrated Regional Information Networks (IRIN). 2009c. Nigeria: Nomad-farmer clashes increase as pasture shrinks. Humanitarian news and analysis

Integrated Regional Information Networks (IRIN). 2010a. Inaction paves way for more bloodshed, observers say. Humanitarian news and analysis

Integrated Regional Information Networks (IRIN). 2010b. Nigeria: Educating the nomads. Humanitarian news and analysis

Integrated Regional Information Networks (IRIN). 2010c. Nigeria: More mass graves dug in Jos. Humanitarian news and analysis

Jabbar, M.A., L. Reynolds, and P.A. Francis. 1995. Sedentarisation of cattle farmers in the derived savannah region of south-west Nigeria: Results of a survey. Tropical Animal Health and Production 27: 55-64.

Joshi, N.R., E.A. McLaughlin, and R. Phillips. 1957. Types and breeds of African cattle. FAO Agricultural Studies no. 37.. Rome: FAO.

Majekodunmi, A.O., A. Fajinmi, C. Dongkum, K. Picozzi, E. MacLeod, M.V. Thrusfield, A.P. Shaw, and S.C. Welburn. 2013. Social factors affecting seasonal variation in bovine trypanosomiasis on the Jos Plateau, Nigeria. Parasites and Vectors 6: 293. doi:10.1186/1756-3305-6-293.

Majekodunmi, A.O., A. Fajinmi, C. Dongkum, A.P.M. Shaw, and S.C. Welburn. 2014. Pastoral livelihoods of the Fulani on the Jos Plateau of Nigeria. Pastoralism: Research Policy Practice 4 (20). doi: 10.1186/s13570-014-0020-7

Markakis, J., and Minority Rights Group International. 2004. Pastoralism on the margin. London: Minority Rights Group International.

Mortimore, M., and W.M. Adams. 1998. Farming intensification and its implications for pastoralism in northern Nigeria. In Prospects for pastoralism in West Africa, ed. I. Hoffman. Giessen: Tropeninstitut.

Moritz, M., B. Kyle, K.C. Nolan, S. Patrick, M.F. Shaffer, and G. Thampy. 2009. Too many people and too few livestock in West Africa? An evaluation of Sandford's thesis. Journal of Development Studies 45(7): 1-21.

Mukasa-Mugerwa, E. 1989. A review of reproductive performance of female Bos indicus (zebu) cattle. ILCA Monograph 6. Addis Ababa: ILCA.

Otchere, E.O. 1982. Productivity of traditional managed white Fulani (Bunaji) cattle in the subhumid zone of Nigeria: Herd size, structures and reproductive characters. ILCA Working Paper. Kaduna: ILCA. https://cgspace.cgiar.org/handle/10568/4413. Accessed 20 Oct 2016.

Oxby, C. 1982. Progress in the settlement of the nomadic herders in the subhumid savannahs of Africa: A study of experiences and administrative arguments for settlement of nomadic herders with special reference to tsetse-freed areas in Nigeria and Upper Volta. Rome: FAO.

Oxby, C. 1984. Settlement schemes for herders in the subhumid tropics of West Africa: Issues of land rights and ethnicity. Development Policy Review 2: 217-233.

Oyedipe, E.O., D.I.K. Osori, O. Akerejola, and D. Saror. 1982. Effect of level of nutrition on onset of puberty and conception rates of zebu heifers. Theriogenology 18: 525-539.

Pullan, N.B. 1979. Productivity of White Fulani cattle on the Jos plateau, Nigeria I. Herd structures and reproductive performance. Tropical Animal Health and Production 11(4): 231-238.

Pullan, N.B., and R.J. Grindle. 1980. Productivity of White Fulani cattle on the Jos Plateau, Nigeria. IV: Economic factors. Tropical Animal Health and Production 12: $161-170$.

Resource Inventory and Management (RIM). 1992. Nigerian livestock resources. Four volume report to the Federal Government of Nigeria by RIM Limited: I. Executive summary and atlas; II. National synthesis; III. State reports; IV. Urban reports and commercially managed livestock survey report. Oxford: Environmental Research Group Oxford.

Sieff, D.F. 1995. The effects of resource availability on the subsistence strategies of Datoga pastoralists of north west Tanzania. PhD Thesis, University of Oxford

Suleiman, H. 1986. Development of grazing reserves and settlement of pastoralists. Paper presented at the Seminar on Second National Livestock Development Projects held at a Durbar Hotel, Kaduna, Nigeria from 9th to 10th December, 1986

Sutter, J.W. 1987. Cattle and inequality: Herd size differences and pastoral production among the Fulani of northeastern Senegal. International African Institute 57(2): 196-218.

Swift, J. 1981. Rapid appraisal and cost-effective participatory research in dry pastoral areas of West Africa. Agricultural Administration 8: 485-492.

Thrusfield, M. 2007. Veterinary epidemiology, revised, 3rd ed. Oxford: Blackwell Science.

van Raay, H.G.T. 1975. Rural planning in a savanna region. Rotterdam: Rotterdam University Press.

von Kaufmann, R., S. Chater, and R. Blench. 1986. Livestock systems research in Nigeria's subhumid zone: Proceedings of the second ILCA/National Animal Production Research Institute (NAPRI) Symposium held in Kaduna, Nigeria 29 October - 2 November, 1984. Addis Ababa: ILCA

Wagenaar, K.T., A. Diallo, and A.R. Sayers. 1986. Productivity of transhumant Fulani cattle in the inner Niger delta of Mali. In Research Report 13, 1-54. Addis Ababa: ILCA.

Waters-Bayer, A., and E. Taylor-Powell. 1984a. Livestock systems research in Nigeria's sub-humid zone-Paper 3: Population and land use in the subhumid zone of Nigeria. Paper presented at the Proceedings of the second ILCA/NAPRI symposium, Kaduna, Nigeria, 29 October - 2 November 1984. Addis Ababa: ILCA.

Waters-Bayer, A., and E. Taylor-Powell. 1984b. Livestock systems research in Nigeria's sub-humid zone-Paper 11: Settlement and land-use by Fulani pastoralists in case study areas. Paper presented at the proceedings of the second ILCA/NAPRI symposium, Kaduna, Nigeria, 29 October - 2 November 1984. Addis Ababa: ILCA.

Williamson, G., and W.J.A. Payne. 1965. Animal husbandry. London: Longmans.

\section{Submit your manuscript to a SpringerOpen ${ }^{\circ}$ journal and benefit from:}

- Convenient online submission

- Rigorous peer review

- Immediate publication on acceptance

- Open access: articles freely available online

- High visibility within the field

- Retaining the copyright to your article

Submit your next manuscript at $>$ springeropen.com 